Scholten, H.J., \& Hooimeijer, P. (1984). The use of vacancy chains and loglinear models to analyse relationships among housing submarkets. Tijdschrift voor Economische en Sociale Geografie, 202213. 


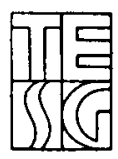

\title{
THE USE OF VACANCY CHAINS AND LOGLINEAR MODELS TO ANALYSE RELATIONSHIPS AMONG HOUSING SUB-MARKETS
}

\author{
by \\ H. J. SCHOLTEN*/** \& P. HOOIMEIJER** \\ The Hague \& Amsterdam, The Netherlands
}

\section{Introduction}

A housing shortage has existed in the Netherlands for a long time; this shortage is generally differentiated as a quantitative or numerical shortage and a qualitative shortage. The quantitative housing shortage simply expresses the need for more dwellings to house the total population. By the end of 1977 the survey of regional housing needs uncovered a shortage of 82,000 dwelling units; the shortage had increased to 127,000 units in 1981 (Regionaal Woningbehoefte Onderzoek 1981). A number of causes for this shortage may be pointed out.

In the first place, the number of households looking for a home increased rapidly from the mid-sixties onward. This is partly due to the coming of age of the post-war baby boom. Another major factor is that the international migration balance has become an immigration surplus. Also, a number of societal changes that increased the number of single-person households stimulated the demand for housing. During the seventies, the quantitative housing shortage was accompanied by an increasing qualitative shortage. The emergence of this mismatch between household and dwelling characteristics correlates with the growth of affluence and the resulting demand for housing of higher standards.

* Planning Division, National Physical Planning Agency, The Hague.

** Geographical and Planning Institute, Free University, P.O. Box 7161, 1007 MC Amsterdam.

Received, December 1983; revised, January 1984.
One of the most important instruments the government has to improve the balance between supply and demand in the housing sector is the construction of new dwellings of a specific type in specific locations.

At present, the quantitative housing needs are still on the rise. Nonetheless, demographic changes make a decrease likely in the future. This will result in a corresponding decrease in residential construction and policies to combat the qualitative housing shortage will be stressed more and more. Because of the decreasing production, adaptations within the existing housing stock will become the main concern of policy. The central issue in future housing policies will be the problem of redistribution; hence, the design of proper instruments for effective housing allocation will become of critical importance. The Netherlands' present housing allocation system can at best block undesired developments from taking place. It does not instigate positive developments; e.g., it does not play an active role in stimulating people to move to dwellings that are more suited to their housing needs. Not even instruments that were specifically designed to promote residential mobility, such as the introduction of extra rent increases for older dwellings in order to equalize the rents of housing of comparable quality but different age ('rent harmonizing'), have produced the desired results.

Until now, new construction has been the most important instrument to bring about the improved matching of households and dwellings. The addition of a new unit to the housing stock generally leads to residential moves within the existing stock; this engenders the so-called vacancy chains. A vacancy chain may be defined 
as "... the sequence of moves made by a vacancy subsequent to its arrival in the $\operatorname{system}(. .$.$) where$ each vacancy is created by the construction of a new unit or by the 'death' of a family..." (White 1971).

The vacancy chain approach can be applied with one or more of the following objects in mind:

1. As a descriptive measure of the multiplier effect of the construction of new housing units;

2. as a means of measuring the benefits to households resulting from relocations generated by new construction;

3 . as a means of evaluating linkages between housing types (housing submarkets) (Bourne 1981).

As soon as the housing production decreases, the capacity to influence residential mobility within the existing housing stock becomes of greater importance in combating the qualitative housing shortage. In this context, it is essential to know exactly what effects the construction of each type of dwelling has on residential mobility. This point highlights the importance of concentrating on the concept of vacancy chains in the analysis of the functioning of a housing market; numerous applications of this approach testify to its usefulness (e.g., White 1971, Adams 1973, Jones 1978, Sharpe 1978).

The common approach in this type of study is as follows: the occupant of a newly constructed dwelling is asked for his previous address; then the present occupant at that address is asked for his previous address, etc. Such an approach, however, is very time consuming. Another major drawback is that each non-response disrupts the particular vacancy chain, as it becomes impossible to localize further households affected. This approach has been adopted almost exclusively in the Dutch vacancy chain research (Kroes \& Vulperhorst 1982). An alternative approach to tracing vacancy chains is the construction of a matrix in which transition probabilities between housing of different types are specified (White 1971). The Ministry of Housing used this method in the report on the programming of residential construction (DGV-MVRO 1982).

The report of the Ministry however, overlooks a number of important characteristics of the ways in which housing markets function. Of basic importance to the understanding of how housing markets function is the question of which sub-markets exist. To distinguish such sub-markets, both the housing stock should be subdivided into appropriate segments (typology of dwelling types), and the total area should be differentiated into spatial sub-markets. For various households only certain segments of the housing market are of interest, given their housing needs, their aspiration and their buying power. The differentiation of housing types should correspond closely to the spectrum of demand, as it will be employed to delineate the submarkets. The spatial level at which an equilibrium of supply and demand is reached may be indicated by the term housing market areas. This is the areal extent within which households move freely without an unacceptable loss of social and cultural contacts and without necessitating a change in place of employment. For each separate housing market area a matrix of transition probabilities must be defined. It may be expected, however, that the patterns of residential moves within each housing market area will show similarities to those in others, which permits generalization in the analysis.

The aim of this research is to describe how the vacancy chain approach can be used to cope with the problems of quantative and qualitative housing needs in the Netherlands.

This article first demonstrates the use of transition probabilities and the resulting vacancy chains. Subsequently, the subdivision of the Netherlands into spatial and sectoral submarkets is described. The ultimate goal of the analysis is to apply the vacancy chain model to one of the spatial sub-markets, in order to derive an optimal program for new construction. However, this article does not proceed that far; instead, the multiplier effect of a selected type of new dwellings is described and the linkages between the various sectoral sub-markets are evaluated.

The empirical data necessary for the study are derived from the survey of regional housing needs that was carried out in 1977 (Regionaal Woningbehoefte Onderzoek 1977). The survey included the questioning of 54,417 individuals and was sponsored by the Ministry of Housing; the Dutch Census Bureau (CBS) was responsible for the data collection. All respondents were asked to describe the characteristics of their present dwelling. Those who had taken up residence there after January 1, 1975 were also asked to describe their previous residence. Anyone who indicated that a move was contemplated was asked about the characteristics of the desired dwelling, including its location.

Three methods of analysis of this data were employed to generate the results presented in 
this article:

1. The multiplier effect was derived by means of input-output analysis;

2. the spatial sub-markets were delineated by using cluster analysis; and,

3 . the loglinear model was employed to distinguish sectoral sub-markets and to analyse the linkages between these sub-markets.

\section{The vacancy chain model}

Each vacancy chain starts with one dwelling that becomes vacant. The vacancy may have various causes: a person or household may die, it may be admitted to an institution, or it may move to a location outside the housing market area; the vacancy may also be the result of a new addition to the housing stock due to new construction. The links in the chain are formed when another household occupies the dwelling vacated by the previous mover. The chain ends when a newcomer to the housing market - either a starter, that is, a newly formed household that moves into its first independent residence, or a migrant from elsewhere - moves into a vacated dwelling.

A common criticism of vacancy chain research points out a theoretical weakness, namely the fact that each individual link in the chain is purely coincidental; the various households that make up the total chain of vacancies are generally entirely unknown to each other. This point would be welltaken if the study were to concentrate solely on individual chains. At the aggregate level, however, rates of movement of vacancies through sub-markets may be observed; these rates provide a measure of interaction between the sub-markets as well as a measure of the turnover generated by new construction (Bourne 1981).

At the same time, this argument provides a reason to ignore the method of tracing individual chains and instead to shift to the registration of all the separate links. The aggregation of these links yields the matrix of all households who moved from a specific type of dwelling to a

Table 1a. Absolute numbers of households.

\begin{tabular}{lllll}
\hline Dwelling of & \multicolumn{3}{l}{ Vacated dwelling } & \\
\cline { 2 - 5 } destination & $\begin{array}{l}\text { Single- } \\
\text { family } \\
\text { dwelling }\end{array}$ & $\begin{array}{l}\text { Dwelling } \\
\text { in multi- } \\
\text { family }\end{array}$ & $\begin{array}{l}\text { New- } \\
\text { comer }\end{array}$ & Total \\
\hline $\begin{array}{c}\text { Single-family } \\
\text { dwelling }\end{array}$ & 40 & 80 & 40 & 160 \\
$\begin{array}{c}\text { Dwelling in } \\
\text { multi-family } \\
\text { structure }\end{array}$ & 100 & 40 & 60 & 200 \\
\hline
\end{tabular}

Table 1b. Relative numbers of households, the so-called recruiting patterns.

\begin{tabular}{lllll}
\hline $\begin{array}{l}\text { Dwelling of } \\
\text { destination }\end{array}$ & \multicolumn{4}{l}{ Vacated dwelling } \\
\cline { 2 - 4 } & $\begin{array}{l}\text { Single- } \\
\text { family } \\
\text { dwelling }\end{array}$ & $\begin{array}{l}\text { Dwelling } \\
\text { in multi- } \\
\text { family }\end{array}$ & $\begin{array}{l}\text { New- } \\
\text { comer }\end{array}$ & Total \\
\hline $\begin{array}{c}\text { Single-family } \\
\text { dwelling }\end{array}$ & $\frac{40}{160}=0,25$ & $\frac{80}{160}=0,50$ & $\frac{40}{160}=0,251,00$ \\
$\begin{array}{c}\text { Dwelling in } \\
\text { multi-family } \\
\text { structure }\end{array}$ & $\frac{100}{200}=0,50$ & $\frac{40}{200}=0,20$ & $\frac{60}{200}=0,301,00$ \\
\hline
\end{tabular}

specific type of dwelling within a given time period. Such a matrix may be derived from the results of the housing needs survey (compare section 1). In turn, this matrix may be used to generate the matrix transition probabilities between the various types of housing (Anderson \& Goodman 1957). This method is illustrated in Tables $1 \mathrm{a}$ and $1 \mathrm{~b}$. The distribution of probabilities which describes the linkages between the type of dwelling selected as destination on the one hand and the types of dwellings vacated on the other is designated from here on in this article as the 'recruiting pattern', which is unique for each type of dwelling.

Then the matrix of transition probabilities may in turn be employed to describe the vacancy chain. Vacated dwellings (the primary supply) may be represented by a vector $(\bar{a})$. The dimension of this vector corresponds with the number of distinguished housing types or sectoral submarkets (n). The components of the vector contain the number of primary vacancies per type. The recruiting pattern of a specified type of dwelling (i) may also be represented by a vector $\left(\bar{p}_{i}\right)$. The dimension of this vector corresponds to the number of distinguished types of dwellings (n), plus two. The two extra components represent the immigrants and the starters in the housing market, respectively.

The recruiting patterns of all distinguished housing types are combined into a recruiting matrix or a transition matrix (P), having $(n \times$ $(n+2))$ dimensions.

Matrix (P) may be subdivided into two separated sub-matrices $(\mathrm{Q})$ and $(\mathrm{R})$. Matrix $(\mathrm{Q})$ combines the transitions between the types of dwellings, and its dimensions are $(n \times n)$. Matrix $(R)$ describes the transitions to dwelling types by immigrants and starters in the housing market and its dimensions are $(n \times 2)$.

The residential mobility process can be represented as an input-output model. This facilitates the determination of the size of the supply 
engendered by a move. The number of dwellings vacant due to primary supply and vacancy chains of a length of two equals $\bar{a}+\bar{a} \cdot Q$. The secondary supply generated by vacancy chains of a length of three equals $\overline{\mathbf{a}} \cdot \mathrm{Q}^{2}$. In general, chains of length $\mathrm{n}$ generate $\overline{\mathrm{a}} \cdot \mathrm{Q}^{\mathrm{n}-1}$ dwellings in the secondary supply'. The total secondary supply, therefore equals

$$
\overline{\mathrm{a}} \cdot \mathrm{Q}+\overline{\mathrm{a}}^{2} \cdot \mathrm{Q}^{2}+\overline{\mathrm{a}} \cdot \mathrm{Q}^{3}+\ldots+\overline{\mathrm{a}} \cdot \mathrm{Q}^{\mathrm{n}}
$$

and the total supply thus equals

$\overline{\mathrm{a}}+\overline{\mathrm{a}} \cdot \mathrm{Q}+\overline{\mathrm{a}} \cdot \mathrm{Q}^{2}+\overline{\mathrm{a}} \cdot \mathrm{Q}^{3} \ldots \ldots+\overline{\mathrm{a}} \cdot \mathrm{Q}^{\mathrm{n}}=$ $\overline{\mathrm{a}}\left(\mathrm{I}+\mathrm{Q}+\mathrm{Q}^{2} \ldots \ldots \mathrm{Q}^{\mathrm{n}}\right)$

$\overline{\mathrm{a}}(\mathbf{I}-\mathrm{Q})^{-1}=$

$\overline{\mathrm{a}} \cdot \mathrm{M}=\overline{\mathrm{b}}$

where $\mathrm{I}$ is the unity matrix and $\mathrm{M}=(\mathrm{I}-\mathrm{Q})^{-1}$.

Matrix $M$ describes the effects of the primary supply on the total supply, vector $\bar{b}$. The type of household that benefits from the supply may be derived from the transition matrix and vector $\bar{b}$. The number of established households that moves, by type of dwelling, equals $\bar{b}$. $Q$ and the number of newcomers for each type of dwelling equals $\bar{b} \cdot R$. By separating the primary supply into existing stock and new completions, the effects of various construction programs may be determined and compared.

If Table $1 \mathrm{~b}$ were to be analysed as an inputoutput matrix, matrix $M$ would first of all yield the chain length for both types of housing contained therein. For the single-family dwellings, the length is 3.71 ; for the dwellings in multi-family structures, the length is 3.57 . This may be interpreted to mean that when one single-family dwelling is vacated, the total resulting supply of housing would be 3.71 dwellings. Table 2 pres- ents two separate elaborations of Table 1, the variation being in two new construction programs. It should be pointed out, however, that the length of the vacancy chains in this example is much longer than would occur in reality. Sharpe (1978), in evaluating the results of eleven separate analyses of vacancy chains, demonstrated that the average length varied from 1.3 to 2.4 links.

\section{The loglinear model}

As mentioned in the introduction to this article, several analyses were carried out by applying the loglinear model. This model has been applied to analyses with a similar structure, all of which utilized categorical data. This data describes the dwellings by function in the residential mobility process (origin or destination), by size, price, tenure category, etc.; and they indicate the sectoral sub-markets. In this section, the general structure of the model is discussed and the application of the model in this particular research project is treated in detail.

The analysis techniques for descerning structures in multivariate categorized data were severely limited until recently. It was the specification of the loglinear model (Birch 1963) and subsequent development of the model and inquiry into the application of this technique (e.g. Bishop, Fienberg \& Holland 1975, Goodman 1978) that made it possible both to identify and to describe the relationships between variables. If a two-dimensional table combining variables $A$ and $B$, of levels $r$ and $c$, respectively, is taken as the point of reference, then the saturated model is specified as:

$$
\log m_{i j}=u+u_{i}^{A}+u_{j}^{B}+u_{i j}^{A B}
$$

where:

Table 2. The multiplier effect of two construction programs.

\begin{tabular}{lllllll}
\hline & Chain length & Vacancies & $\begin{array}{l}\text { Resulting } \\
\text { supply }\end{array}$ & $\begin{array}{l}\text { New con- } \\
\text { struction }\end{array}$ & $\begin{array}{l}\text { Resulting } \\
\text { supply }\end{array}$ & $\begin{array}{l}\text { Total } \\
\text { supply }\end{array}$ \\
\hline $\begin{array}{l}\text { Program A } \\
\text { Single-family } \\
\text { dwelling }\end{array}$ & 3.71 & 100 & 371 & 60 & 280 & 651 \\
$\begin{array}{l}\text { Dwelling in } \\
\text { multi-family } \\
\text { structure }\end{array}$ & 3.57 & 100 & 357 & 100 & 300 & 657 \\
$\begin{array}{l}\text { Program B } \\
\text { Single-family } \\
\text { dwelling } \\
\begin{array}{l}\text { Dwelling in } \\
\text { multi-family }\end{array}\end{array}$ & 3.71 & 100 & 371 & 100 & 314 & 686 \\
structure & 3.57 & 100 & 357 & 60 & 271 \\
\hline
\end{tabular}




$$
\begin{aligned}
& u=\frac{1}{r \cdot c} \sum_{i j} \log m_{i j} \\
& u_{i}^{A}=\frac{1}{c} \sum_{j} \log m_{i j}-u \\
& u_{j}^{B}=\frac{1}{r} \sum_{i} \log m_{i j}-u \\
& u_{i j}^{A B}=\log m_{i j}-u-u_{i}^{A}-u_{j}^{B}
\end{aligned}
$$

It is possible to check whether certain parameters may be eliminated from the model (test of independence). The model can easily be elaborated to more dimensions. The parameters of the model have an obvious statistical interpretation. The parameter $u$ corresponds to the overall mean effect, the parameters $u_{i}^{\mathrm{A}}$ and $u_{j}^{\mathrm{B}}$ describe the effect of the variables $A$ and $B$, and the parameters $u_{i j}^{A B}$ comprise the interaction effect between $\mathrm{A}$ and $\mathrm{B}$.

The model may also be expressed in a multiplicative mode, where the parameters take on the exponential form of the corresponding parameters of the additive model:

$$
\mathrm{m}_{\mathrm{ij}}=\mathrm{w} \cdot \mathrm{w}_{\mathrm{i}}^{\mathrm{A}} \cdot \mathrm{w}_{\mathrm{j}}^{\mathrm{B}} \cdot \mathrm{w}_{\mathrm{ij}}^{\mathrm{AB}}
$$

To arrive at a typology of dwellings, all variables selected on the basis of theory may be combined in one model. Subsequently, the extent to which the variables and interaction effects contribute significantly to the typology may be tested. The evaluation of the linkages between the various types of dwellings may be based on the application of the saturated model. The interaction parameters $\mathrm{w}_{\mathrm{ij}}^{\mathrm{AB}}$ provide an exact measure of these linkages, after elimination of the effects of size of the sub-populations of dwellings of origin and destination.

\section{The spatial sub-markets}

The spatial level at which the analysis of the migrations should be carried out was defined in the introduction to this article. The matching of supply and demand takes place within housing market areas, and these areas form the building blocks of the study area. The delimination of the 46 housing market areas by the Directorate General of the Ministry of Housing was taken as the starting point.

In order to determine a stable and homogeneous recruiting pattern, it is important to include a large number of migrants in the study. The housing needs survey of 1977 (RWBO 1977), solicited information from many individuals, but the total number of movers among them amounted to only approximately twenty percent. The number of interviewed migrants in each separate housing market area, therefore, is too small to allow the construction of recruiting patterns on the basis of the recorded moves. To increase the number of movers to form a sufficiently large group, several individual housing market areas must be combined. This procedure was applied to housing market areas which strongly resembled each other with respect to the composition of the housing stock. Thus, homogeneous regions emerge; moreover, it may be assumed that the mobility patterns within the housing market areas that are combined into these regions are similar in nature.

Based on the data of the housing stock of individual municipalities, the relative share of a large number of dwelling types per housing market area was calculated. To eliminate the disturbing influence of the evidently deviant composition of the housing stock in the largest cities, these municipalities were ignored in the process. The combination was achieved by means of cluster analysis ${ }^{2}$. The resulting clusters were not required to be composed of spatially continuous housing market areas.

Nevertheless, the final solution in which four clusters emerge (Fig. 1) clearly demonstrates the

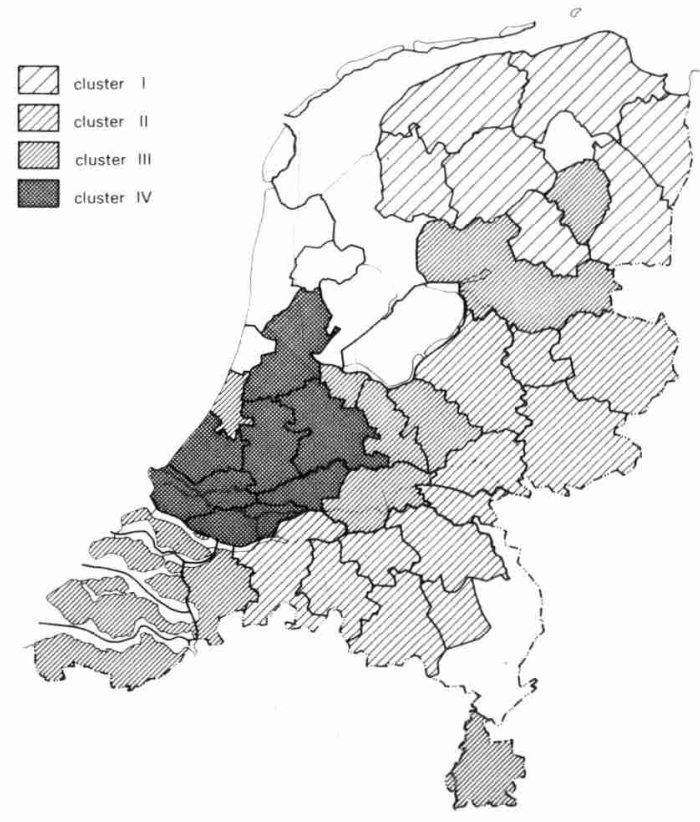

Fig. 1. Spatial sub-markets. 
existence of an obvious spatial pattern with respect to the housing stock composition of the 46 housing market areas. The housing market areas which are not shaded on the map could not be classified unambiguously. At this point, each of the four resulting clusters may be used to determine the recruiting patterns. It may be expected that each of the recruiting patterns of these clusters will be different. For the present research, the southeastern region of the Netherlands was selected for further study (cluster II).

It should be emphasized that within the cluster, the combined housing market areas are considered as separate units; this is of importance in regard to identifying the group of immigrants in the housing market areas. Each individual who moves within the region, but from one housing market area to another, will be considered as an immigrant in the destination area and thus as a newcomer in its housing market.

\section{The sectoral sub-markets}

The usefulness of the model depends to a great extent on the dwelling types that are distinguished in the design of the transition matrix. These have to correspond with the factors that structure the demand (housing needs and aspirations of the household), and to the influences on housing supply (measures that determine the programming of new construction, conversion of tenure, and housing allocation policies). In addition, two criteria have to be met:

The typology should give rise to homogeneous transition probabilities, which means that further subdivision of a specific type may not lead to essentially different transition probabilities;

the typology may not become too detailed; if the number of categories is too large, the cells of the matrix will contain too few observations and then they can no longer be considered as probabilities.

The most important characteristics of households that determine housing needs and aspirations are family status position and socio-economic status. Especially (anticipated) changes in these characteristics help to explain residential moves (Brown \& Moore 1970, Michelson 1977). Obviously, this observation does not help to determine the relevant dwelling characteristics on which the typology is to be constructed; these household characteristics may indeed be the basis for a great variety of the households' demands with respect to their housing situation. Individual households searching for a different home have to wield a large number of criteria in order to evaluate the alternatives. Many of these criteria, however, prove to be highly interrelated ; the selection of a limited number of key-variables may thus suffice (Brown \& Moore 1970). From a brief survey of empirical migration studies (for instance, Rossi 1980, Speare et al. 1975, Dieleman 1983) a limited number of such key variables emerges:

1. Tenure (rental/owner-occupier);

2. structure type (single-family/multi-family);

3. size of the dwelling;

4. price of the dwelling.

Dutch housing research even suggests the existence of a hierarchy of desired dwellings, which is completely composed of value combinations of the first two variables (Priemus 1979, Van der Schaar 1979).

Whether or not the most desired dwellings are accessible depends predominantly on the buying power of the household; the price to be paid is the most important selection factor. Low-income households run into significant barriers if they desire to move into the owner-occupier sector. Policy measures designed to increase the accessibility of this sector (such as the payment of subsidies) are predominantly used by young households with good prospects for income growth. Similar programs designed for renters (such as rent supplement payments) also yield insufficient results, mainly because the rapidly escalating non-rent costs of housing (service charges, utilities) are excluded from the subsidy calculations.

Apart from the pricing mechanism, the housing allocation rules as implemented by the housing authorities (municipalities and the non-profit housing associations) play an important role. These rules differ widely between and even within regions. (An elaborate overview of the housing policies is to be found in Van Weesep 1982.)

The most important housing characteristics that determine housing allocation (Nauta 1979) are:

- The price of the dwelling;

- tenure;

- structure type;

- size of the dwelling;

- age (new construction/ existing dwellings).

Thus, it is apparant that both the supply and the demand for housing are structured by the same four dimensions: tenure, price, size and structure type. Each of these dimensions has clear cut-off points, which reflect not only the contrasting housing needs and aspirations of various groups of households, but also the barriers within the housing market. The combination of 
Table 3. The typology of cluster II.

Housing type

Chain

length

1. Single-family rental dwelling, two or three rooms, and a monthly rent below 200 guilders (price level July 1, 1977)

2. Single-family rental dwelling, two or three rooms, and a monthly rent of 200 guilders or more

3. Single-family rental dwelling, four rooms, and a monthly rent below 200 guilders

4. Single-family rental dwelling, four rooms, and a monthly rent between 200 and 350 guilders

5. Single-family rental dwelling, four rooms, and a monthly rent of 350 guilders or more

6. Single-family rental dwelling, five or more rooms, and a monthly rent below 250 guilders

7. Single-family rental dwelling, five or more rooms, and a monthly rent between 250 and 400 guilders

8. Single-family rental dwelling, five or more rooms, and a monthly rent of 400 guilders or more

9. Rental dwelling in multi-family structure, two or three rooms, and a monthly rent below 200 guilders

10. Rental dwelling in multi-family structure, two or three rooms, and a monthly rent of 200 guilders or more

11. Rental dwelling in multi-family structure, four or more rooms, and a monthly rent below 300 guilders

12. Rental dwelling in multi-family structure, four or more rooms, and a monthly rent of 300 guilders or more

13. Owner-occupier dwelling valued below 150,000 guilders (price level July 1, 1977)

14. Owner-occupier dwelling valued at 150,000 guilders or more (price level July 1, 1977)

each of these dimensions results in a differentiation of the housing market into sectoral submarkets. The entire typology which pertains to the spatial sub-market of the southeastern part of the Netherlands (cluster II) is presented as Table 3 .

Depending on the number of categories specified for each dimension, it is evident that the total number of types may grow to unwieldy proportions. If so, the criterion of sufficient respondents in each cell of the matrix becomes of prime importance. It should be noted at this point that such an insufficient number of observations in a specific cell may be interpreted as an indication that few or no moves take place between the two relevant dwelling types. It is not the number of observation in each cell that is of critical importance; rather the marginal totals should be of sufficient magnitude to allow for a meaningful differentiation. In the case at hand, this led to the requirement that the unweighted marginal totals show at least seventy respondents.

If in order to promote the stability of the transition probabilities, it is imperative that not too many types be created, the second criterion the required homogeneity - demands that not too few be recognized. The solution to this dilemma was found in testing the possibility to combine separate types by means of the loglinear model. The fourteen resulting types, as listed in Table 3, prove to have recruiting patterns that are significantly different. The nature of these recruiting patterns is discussed in the following section.

\section{Vacancy chains in the southeast of the Nether-} lands

Generally, vacancy chain analysis leads to the conclusion that the availability of expensive owner-occupier dwellings results in the longest chain. However, when the average chain length of various types of dwellings in a housing market area is calculated, it proves that other types of dwellings have long chains as well (Table 3). In the southeastern region of the Netherlands, the multiplier effect of low-priced four-room single family homes (type 3 ) is even larger than that of expensive owner-occupier dwellings (type 14). A number of causes for this deviation may be advanced:

A number of studies trace the vacancies to beyond the region itself (Lansing et al. 1969). But in this study, the immigrants from outside the regional housing market are considered to be newcomers, thus terminating the chain. The probability of an immigrant taking the vacancy is largest when the vacant dwelling belongs to the expensive category.

As shown below, the low-priced single-family homes are relatively inaccessible to immigrants, as this part of the housing supply is shielded from outside competition by the rules for housing allocation; the chain length of this type is thereby increased.

- Most vacancy chain analyses study the effects of new construction only. Since it is virtually impossible to construct new dwellings of type 3 , this group forms a small proportion of the total number of vacancies in these studies.

The discovery that construction of expensive dwellings leads to the longest chain has had important repercussions. In the Netherlands, Britain and North America, policy regarding 


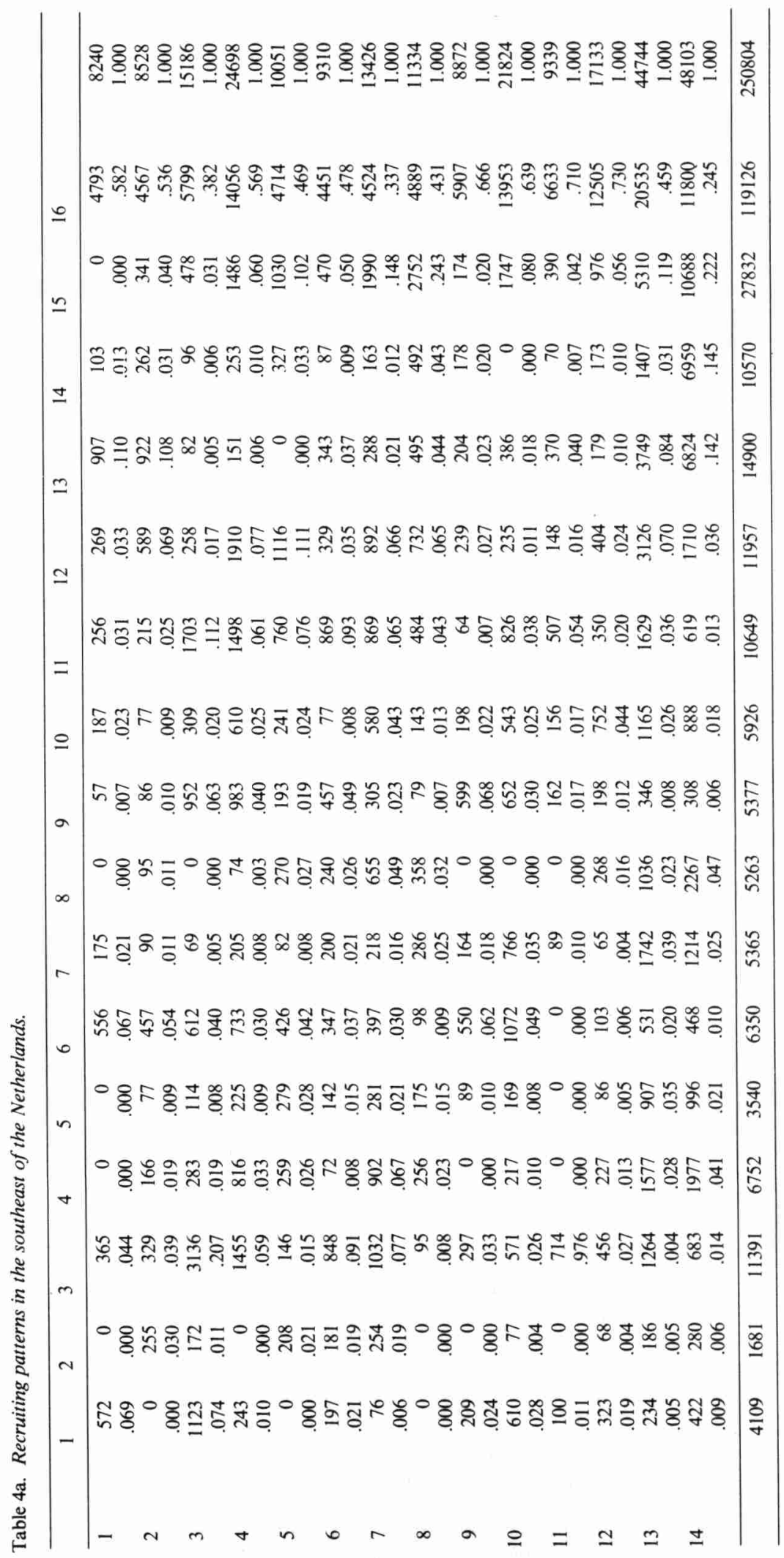


construction programmes has capitalized on the 'trickling down' effects of the addition of expensive new dwellings. However, the criticism has also been frequently voiced that the vacancy chains are generally terminated before any effects are created for the housing markets in which low-income households operate (Sharpe 1978, Watson 1974, Priemus 1979). This can lead to only one conclusion. The analysis should not stop at calculating the average chain lengths but should proceed beyond this point. To explain the differences in chain length it is imperative to study the position of newcomers in the various sub-markets. In addition, the composition of the vacancy chain must be analysed, as this may be of greater importance than determining the length of the chain. This requires sufficient insight in the flows of moves between the various sub-markets.

Table 4a presents the weighted numbers of respondents who gained access to a dwelling in the southeast of the Netherlands in the years 1975,1976 or 1977 . In the rows of the table, the number of occupied dwellings per type is presented. The columns present the number of vacated dwellings; columns 15 and 16, however, are reserved for newcomers, immigrants from other housing market areas and starters, respectively. The starters are a very sizable group, since they occupied almost fifty percent of all available dwellings.

The transition probabilities have been recorded underneath the absolute numbers. When an entire row is considered, these transition probabilities represent the recruiting pattern of a specific type of dwelling. This provides direct information regarding which types of dwellings will function as the first links in the vacancy chain that results when a dwelling of the specific type is vacated. The analysis of the flows between sub-markets may thus proceed on the basis of this table. A major hindrance to such an approach is that the cells present the absolute size of the flows. Thus, in almost all submarkets, the migration to the low-priced owneroccupier type is by far the largest flow; this is caused by the fact that this housing type predominated over the other to such a large extent. For a correct insight in the magnitude of the interaction between sub-markets, it is thus necessary to apply a correction to the flow based on the marginal total. For this procedure, the saturated loglinear model was used.

As described above, this model differentiates the flows by four types of parameters. The value of the parameters are presented in Table $4 \mathrm{~b}$. The multiplicative form of the model was selected for this application:

$$
\mathrm{m}_{\mathrm{ij}}=\mathrm{w} \cdot \mathrm{w}_{\mathrm{i}}^{\mathrm{A}} \cdot \mathrm{w}_{\mathrm{j}}^{\mathrm{B}} \cdot \mathrm{w}_{\mathrm{ij}}^{\mathrm{AB}}
$$

The absolute value of each cell may thus be reconstructed by multiplying the values of the appropriate parameters. As the parameter value approaches 1, the specific effect of the parameter in question is of less importance.

a. The parameter $w$ represents the overall mean effects. Its value is relatively large (233.61) due to the weighting procedure, which increased the number of cases from 2531 to 250,785 .

b. The parameter $w_{i}^{A}$ indicates the effect of the relative share of each sub-market among all occupied dwellings. Its values have been included as the last column of the table.

c. The parameter $w_{j}^{B}$ represents the corresponding effect of the vacated dwellings; its values have therefore been included as the bottom row of the table.

d. Finally, the interaction parameter $w_{i j}^{A B}$ represents in this case the linkages between the sub-markets, as corrected for the relative share of each sub-market and for the total sample size. Because the interaction effects may be directly compared within each row and each column, this parameter facilitates a quick evaluation of specific interaction patterns. It is thus relatively simple to trace the position of newcomers in the housing market and also to determine the composition of the housing chains.

A strongly deviating pattern from the average may be expected to be associated with the position of the group of starters, both with respect to their demand and with respect to the supply of housing available to them. Their housing desires may be summarized as 'small and cheap'. The supply of housing for this group is in part composed of newly constructed so-called HAT units (that is, cheap rental units specifically designed for occupancy by single persons or by two-person households). Generally, housing allocation regulations link the size of the dwelling to the number of persons in a household. In addition, single-family dwellings are often reserved for households that have already lived in an apartment in a multi-family structure for several years (Nauta 1979).

These regularities are confirmed by the data in Table $4 \mathrm{~b}$. The values of the parameters in column 16 demonstrate that the number of starters 


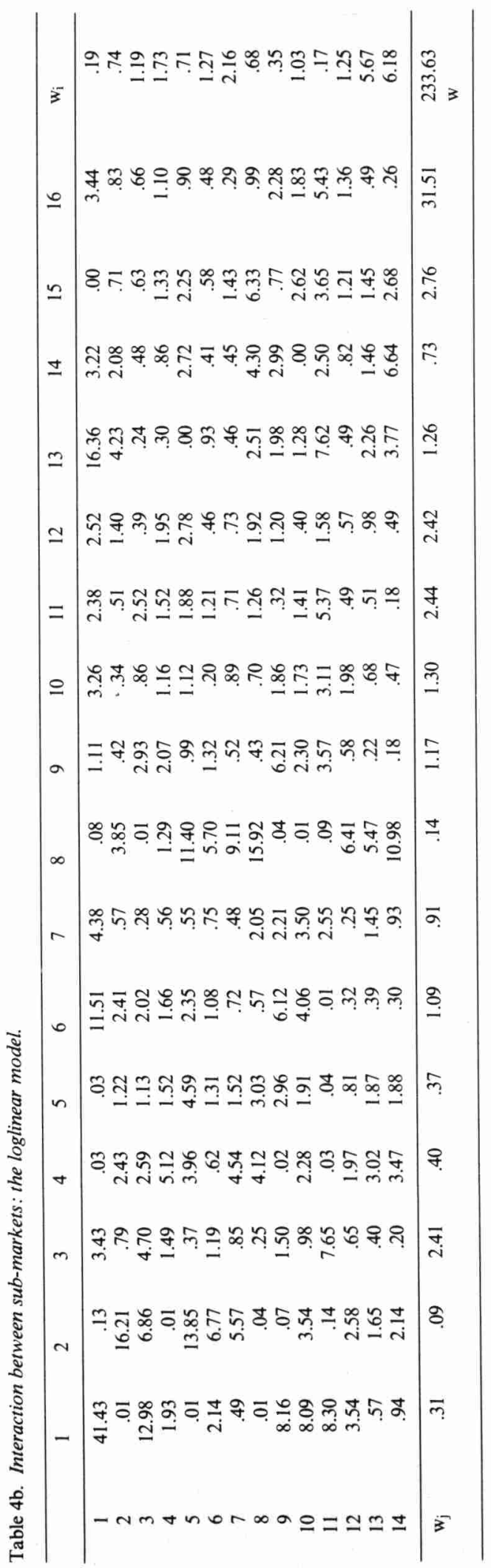


that move into an owner-occupier dwelling is far below average (types 13 and 14). A sizable overrepresentation, on the other hand, may be noted in types 9 through 12 , the dwellings in multi-family structures; among these types the cheaper ones show higher score than the more expensive ones. The starters are under-represented in the group that moves into single-family dwellings; only among the households that move into cheap, small dwellings (type 1) or into four room dwellings of moderate price are the starters well represented. This last correspondence may be the result of the common practice of allocating new four-room subsidized rental dwellings to starters in anticipation of a growing family.

To some extent, the interaction pattern of the migrants may be somewhat contradictory to that of the starters. Among the long-distance movers, higher-income households are slightly overrepresented. This group has a clear preference for owner-occupier dwellings and for the more expensive rental dwellings. This preference is augmented by supply factors. Many local housing authorities explicitly try to reserve the available low-price (rental) dwellings for the local population. In addition, long waiting lists for this type of accomodation are common, especially for the low-price single-family dwellings.

Column 15 of Table $4 \mathrm{~b}$ demonstrates that, indeed, for all types of single-family dwellings and for all owner-occupier dwellings the migrants interact most strongly with the most expensive sub-type. This regularity is less clear-cut for the dwellings in multi-family structures, but this can easily be explained. In many places the supply of large, moderately priced dwellings in multi-family structures is relatively large. (As may be observed in Table 4a, this is the only type where the number of vacated units is larger than the number of units selected.) Because of relatively short waiting periods, migrants may easily take up their initial residence in a dwelling of this type and subsequently move on to a more desired dwelling of the single-family type (compare column 11):

It may be concluded that the housing authorities themselves are largely responsible for the different lengths of the vacancy chains of the various types of dwellings. The position of the newcomers in the housing market is influenced by their buying power, but also to a significant extent by the rules of the housing allocation systems.

The differences in the composition of the vacancy chains are reflected in the recruiting patterns. It should be noted, however, that the tran- sition probabilities recorded in Table $4 \mathrm{a}$ are also influenced by the number of vacated dwellings of a given type. This column effect does not occur in the interaction parameters. For the construction program the interactions of the owneroccupier sector are of special significance.

Table $4 \mathrm{~b}$ demonstrates how closely the interaction patterns of both low-price and of expensive owner-occupier dwellings resemble each other. They both have very weak interactions with both the dwellings in multi-family structures and with cheap single-family rental dwellings; this last category is very important to low-income households. The mobility within the owner-occupier sector, on the other hand, is substantial, and a large flow from expensive rental dwellings (type $8,4,5$ ) to the owner-occupier sectors may also be noted. Expensive rental dwellings are vacated in especially the second link of these vacancy chains. But also the interactions of expensive rental dwellings with the cheaper ones are of minor proportions, with the exception of type 4 . This leads to the conclusion that not even the second link in the chain, caused by the addition of expensive dwellings, reaches the desired sub-markets.

The criticism voiced with regard to the filtering policy, questioning the occurrence of positive effects of the construction of expensive dwellings for lower income groups, is thus substantiated by this analysis. In the subsequent stages of this research project, the various sub-markets will be further analysed, to make specific recommendations regarding the desired differentiation of the residential construction programs.

\section{Conclusions}

The reconstruction of entire individual vacancy chains is irrelevant from a theoretical point of view. The transition from one dwelling to another is independent of the position of these dwellings in the vacancy chain. Because of this, the residential mobility proces is amenable to inputoutput analysis.

This approach is more efficient: it is sufficient to register the characteristics of the vacated dwelling for each destination dwelling. This permits the utilization of data from the regional housing needs survey, which facilitates a further detailing of existing analysis. Such detail is necessitated by the segmentation of the housing market into spatial and sectoral sub-markets.

Provided these sub-markets are dilimitated appropriately, the transition matrix can be used as a basis for analysing both the quantitative and the qualitative aspects of the multiplier effect of 
new construction. Loglinear analysis of the mobility matrix proved to be a useful tool for evaluating the linkages between the sub-markets. The interaction parameters reflect the magnitude of these linkages corrected for the effect of size of the sub-markets.

On the basis of the results of this research an input-output model to trace the multiplier effects of a specified differentiation of residential construction programs within the various submarkets can be constructed. The transition ma- trix is the core of this model. The performance of the model will be determined by the homogeneity and stability of the transition probabilities. As a consequence, these will have to be tested and, if necessary, improved.

Application of the model will only be useful if it is clear which sub-markets are characterized by shortages. The results of the tests on homogeneity and stability and an application of the model based on the analysis of housing shortages will be presented by the authors shortly.

2 Because in this case the internal homogeneity of the clusters is dominant, two non-hierarchical procedures were selected; namely, mode analysis and iterative relocation (Wishart 1969, Deurloo \& Op’t Veld 1983).

This study was partly supported by Adviesgroep Partners B.V., physical planning and design agency.

LANsing, J. B. et al. (1969), New Homes and Poor People. A Study of Chains of Moves. An Arbor: University of Michigan Press.

Michelson, W. (1977), Environmental Choice, Human Behaviour and Residential Satisfaction. New York: Oxford University Press.

NAUTA, A. (1979), Inventarisatie Toewijzingsregels. Deel I: Methodische Inleiding op het Onderzoek. Rotterdam: Stichting Bouwcentrum.

PRIEMUS, H. (1979), Sterkere bewonersgroepen wonen doorgaans goed en zwakke slecht. Bouw nr. 7, pp. 38-41.

Regionaal Woningbehoefie Onderzoek (1977, 1981), Den Haag: Ministerie van Volkshuisvesting en Ruimtelijke Ordening.

Rossi, P. H. (1980), Why Families Move, Second Edition. Beverly Hills: Sage Publications.

SCHAAR, J. van der (1979), Sector-indelingen en woningmarktprocessen. Den Haag: Staatsuitgeverij.

Sharpe, C. A. (1978), New Construction and Housing Turnover: Vacancy Chain in Toronto. Canadian Geographer XXII, 2, pp. 130-144.

SPEARE, A. J., S. Goldstein \& W. Frey (1975), Residential Mobility, Migration and Metropolitan Change. Cambridge: Ballinger.

Watson, C. J. (1974), Vacancy Chains, Filtering and the Public Sector. Journal of the American Institute of Planners 40, 5, pp. 346-352.

WEESEP, J. van (1982), Production and Allocation of Housing: The Case of the Netherlands, Geografische en Planologische Notities, 11. Amsterdam: Vrije Universiteit.

WhITE, H. C. (1971), Multipliers, Vacancy Chains and Filtering in Housing. Journal of the American Institute of Planners 37, 2, pp. 88-94.

WisharT, D. (1969), Mode Analysis: A Generalisation of Nearest Neighbour with Reducing Chaining Effects, In: A. G. COLE ed., Numirical Texonomy, pp. 282-311. London: Academic Press. 


\section{THE NETHERLANDS IN MAPS}

Percentage of votes cast for the Labour Party and the Liberal Party at the election for the provincial parliaments at 24.III.1982, by polling district.
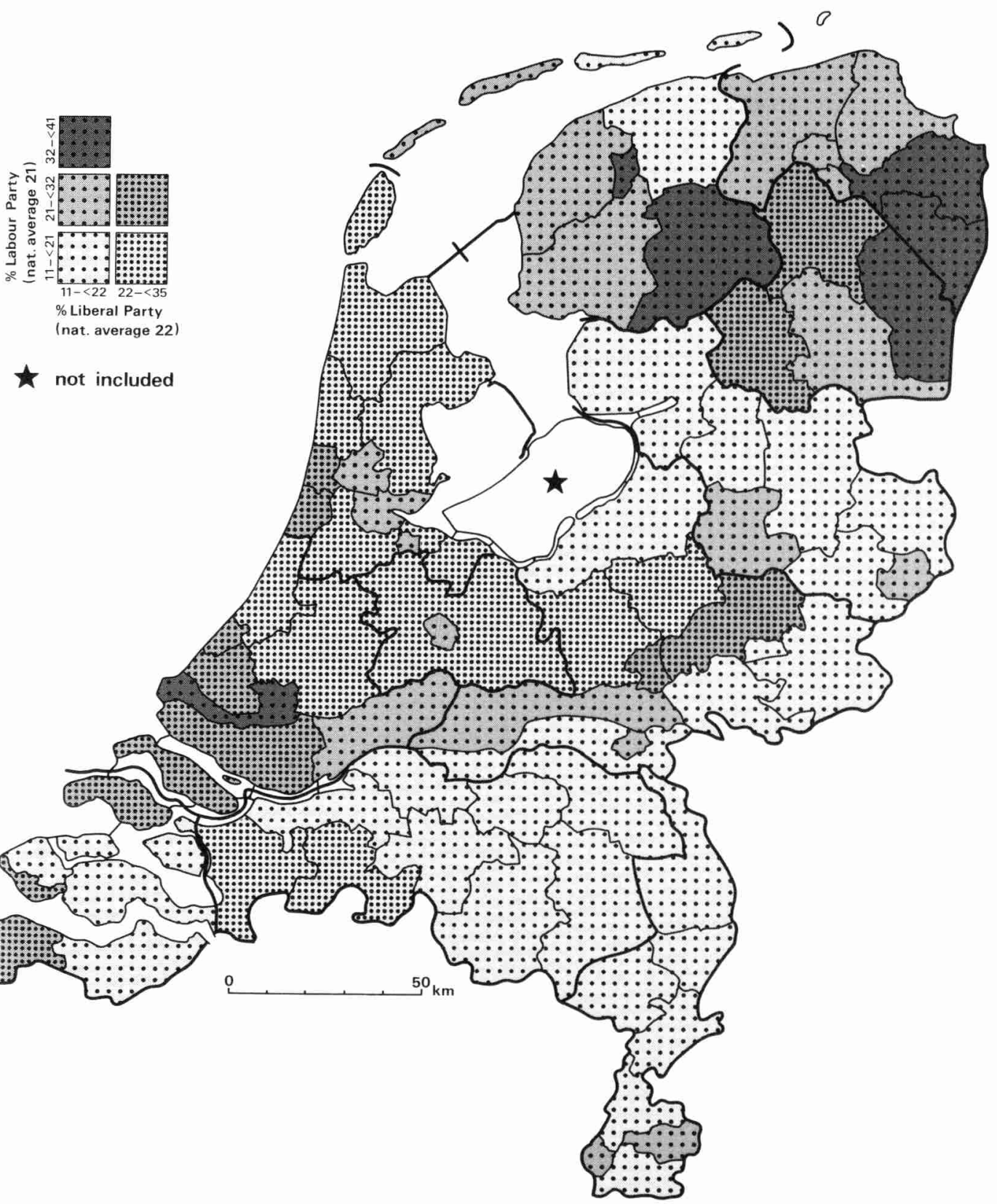

Basic source: Central Bureau of Statistics.

(C) R. Tamsma GIRUG

Tijdschrift voor Econ. en Soc. Geografie 75 (1984) 3 